\title{
RESPONS PSIKOSOSIAL DAN KESEJAHTERAAN PSIKOLOGIS PASIEN FILARIASIS DI KOTA AMBON
}

\author{
Melany S. Reasoa ${ }^{1}$, Yulius Y. Ranimpi ${ }^{2}$, R. Rr. Maria D. Kurniasari', \& Fiane de Fretes ${ }^{1}$ \\ ${ }^{1}$ Program Studi Ilmu Keperawatan, Fakultas Kedokteran dan Ilmu Kesehatan, Universitas Kristen Satya Wacana, \\ Jln. Kartini, 50711, Jawa Tengah, Indonesia \\ ${ }^{2}$ Fakultas Teologi, Universitas Kristen Satya Wacana, Jln. Kartini, 50711, Jawa Tengah, Indonesia
}

Korespondensi:

2e-mail:yulius.ranimpi@staff.uksw.edu

\begin{abstract}
Filariasis (elephantiasis) is a tropical disease and is pendemic in many regions in Indonesia. Filariasis is caused by transmission of microorganisms through mosquito bites. Although filariasis is not lethal, the resulting physical disability will lead to psychological pressures of the sufferers, such as: depression, anxiety, lack of productivity and social interest. While psychosocial responses of the sufferers could be negative or positive, the positive response is believed to assist the sufferers in achieving well-being. The purpose of this study was to describe the psychosocial and well-being responses of filariasis patients. This study used in-depth interviews to two participants, approached through purposive sampling. The results emerged in four categories: 1). not excluded, 2). optimistic, 3). negative impact, and 4). social relations. The study concludes that physical disability experieced by the participants resulted in being dependent to others, which led to negative social treatment. However, participants achieved well-being from the fact that they were not excluded by their family; this gained a sense of optimistic and social interest to relate with their environment.
\end{abstract}

Article history:

Received 5 January 2019

Received in revised form 29 July 2019

Accepted 19 October 2019

Available online 5 November 2019

Keywords:

filariasis;

psychological response;

well-being

\begin{abstract}
Abstrak - Filariasis (kaki gajah) merupakan penyakit tropis yang sangat umum dijumpai di beberapa daerah di Indonesia dan disebabkan oleh penularan mikroorganisme melalui gigitan nyamuk. Meskipun filariasis tidak mengakibatkan kematian, kecacatan yang ditimbulkan dapat berdampak pada tekanan psikologis penderita, seperti: depresi, kecemasan, serta melemahnya produktivitas dan minat sosial. Walau respons psikososial penderita dapat berupa pemikiran negatif dan positif, pemikiran positif dapat mengarahkan penderita untuk mencapai kesejahteraan psikologis. Tujuan penelitian ini ialah untuk mendeskripsikan respons psikososial dan kesejahteraan psikologis pada pasien filariasis. Wawancara mendalam dilakukan terhadap dua partisipan yang direkrut melalui teknik purposive sampling. Hasil studi terangkum dalam empat kategori: tidak dikucilkan, optimis, dampak negatif, dan hubungan sosial. Kecacatan yang dialami partisipan mengakibatkan ketergantungan terhadap orang lain serta mendapat perlakuan negatif. Namun, kesejahteraan psikologis partisipan dipengaruhi oleh kondisi bahwa ia tidak dikucilkan oleh keluarganya, sehingga memunculkan optimisme dan minat sosial untuk terus menjalin relasi sosial dengan lingkungan yang lebih luas.
\end{abstract}

Kata Kunci: filariasis; kesejahteraan psikologis; respons psikososial 


\section{PENDAHULUAN}

Filariasis merupakan penularan mikroorganisme melalui nyamuk yang menjadi penyebab penyakit pada masyarakat di Indonesia. Filariasis adalah penyakit parasit yang termasuk ke dalam penyakit terabaikan (neglected disease) dan penyakit tersembunyi (silent disease) (Hadisiwi \& Mulyani, 2013). Filariasis dikatakan sebagai penyakit terabaikan karena termasuk dalam penyakit tropis. Penyakit tropis terabaikan merupakan penyakit yang sangat umum terjadi, khususnya di wilayah berkembang. Penyakit tropis biasanya berupa parasit, salah satunya cacing (Aprilliani \& Mustafidah, 2017). Filariasis juga merupakan penyakit tersembunyi karena ketika seseorang terinfeksi oleh gigitan nyamuk yang mengandung larva, infeksi filariasis baru diketahui setelah larva berkembang menjadi cacing yang sudah dewasa dengan melakukan pengecekan darah (Masrizal, 2013). Filariasis dapat menimbulkan dampak fisik, sosial, dan ekonomi. Dampak fisik yang ditimbulkan adalah pembengkakan yang disebabkan oleh kerusakan pada sistem limfatik, sehingga mengakibatkan pembengkakan pada organ motorik, payudara, dan buah zakar, sedangkan dampak sosialnya berupa gangguan interaksi sosial dan keterlibatan dalam kegiatan sosial, serta minimalnya kesempatan untuk menikmati waktu hiburan. Selain itu, penderita dan keluarga akan mengalami penurunan finansial karena biaya pengobatan yang tidak sebanding dengan produktivitas selama proses pengobatan (Kementerian Kesehatan RI, 2010).

Pada tahun 2014, kasus filariasis menyerang 1,103 juta orang di 73 negara yang berisiko filariasis. Kasus filariasis menyerang 632 juta (57\%) penduduk yang tinggal di Asia Tengara (9 negara endemis) dan 410 juta (37\%) penduduk yang tinggal di wilayah Afrika (35 negara endemis) (World Health Organization [WHO], 2016), sedangkan, siasanya (6\%) diderita oleh penduduk di wilayah Amerika (4 negara endemis), Mediterania Timur (3 negara endemis), dan wilayah barat Pasifik (22 negara endemis). Indonesia termasuk dalam negara endemis penyakit filariasis di hampir seluruh wilayah daerahnya. Hingga saat ini, di Indonesia telah terindentifikasikan 23 spesies nyamuk dari lima genus yang menyerang, yaitu Mansonia, Anopheles, Culex, Aedes dan Armiges yang menjadi vektor filariasis. Wilayah Indonesia Barat memiliki prevalensi yang cukup rendah dibandingkan Indonesia Timur. Jumlah penderita kronis filariasis di wilayah Indonesia Timur ialah 11,914 yang tersebar di Nusa Tenggara Timur (NTT), Papua, Sulawesi, dan Maluku. NTT merupakan provinsi dengan penderita filariasis terbanyak (2,864 penderita) dan Maluku merupakan penderita filariasis dengan jumlah yang sedikit (70 penderita) (Infodatin, 2016). Hal ini dikarenakan 
wilayah Indonesia Timur banyak terdapat rawa dan wilayahnya sangat dekat dengan pantai yang menyebabkan banyak nyamuk berkembang biak (Masrizal, 2013).

Selain daerah tersebut, penyakit filariasis juga telah menyebar ke daerah lain di Indonesia, seperti: Aceh, Papua Barat, Jawa Barat, Kalimantan Timur, dan Jawa Tengah yang merupakan daerah dengan tingkat endemik yang cukup tinggi. Berdasarkan data Dinas Kesehatan Indonesia (2015), kasus kronis filariasis meningkat dari tahun 2002 hingga 2014 dengan jumlah penderita sebanyak 14,932 orang. Peningkatan ini disebabkan banyaknya kasus baru yang ditemukan seiring pelaksanaan pendapatan sarana sebelum Pemberian Obat Pencegahan Masal (POPM) filariasis (Infodatin, 2016).

Di Maluku, jumlah penderita filariasis dari tahun 2010 sampai 2014 bersifat fluktuatif (Dinas Kesehatan Maluku, 2015). Terdapat 10 penderita pada tahun 2010 dan meningkat tinggi sebesar 176 penderita di tahun 2011. Pada tahun 2012, angka penderita mengalami penurunan dengan 17 penderita dan kembali meningkat menjadi 172 penderita di tahun 2013. Tahun 2014 dilaporkan adanya kasus filariasis (kronis) sebanyak 35 penderita yang tersebar di enam kabupaten atau kota di Pulau Ambon, kecuali Kabupaten Maluku Tenggara. Kota Ambon merupakan penyumbang terbanyak kasus filariasis, yaitu 16 penderita, diikuti oleh Kabupaten Seram Bagian Barat (SBB) sebanyak 11 penderita dan Maluku Tenggara Barat (MTB) sebanyak lima penderita. Kejadian filariasis terlaporkan karena peran aktif dari kabupaten atau kota untuk melapor ke Dinas Kesehatan Provinsi. Kota Ambon dan Maluku Tengah merupakan dua wilayah di Provinsi Maluku yang telah melakukan pengobatan yang masih terbatas. Namun, pelacakan melalui survei darah jari untuk mengetahui microfilaria rate (presentase angka mikrofilaria) belum terlaksana secara maksimal karena minimalnya ketersediaan dana, sehingga Maluku belum berhasil menurunkan angka mikrofilaria dibandingkan dengan beberapa provinsi di Indonesia Timur lainnya (Kementerian Kesehatan RI, 2019).

Filariasis tidak menyebabkan kematian, namun filarisasis menjadi penyebab utama timbulnya kecatatan, stigma sosial, hambatan psikososial, dan menyebabkan penurunan produktivitas kerja individu maupun keluarga, serta menimbulkan kerugian ekonomi yang besar (Noerjoedianto, Ekawaty, \& Herwansyah, 2013). Kecatatan yang dialami akan membuat para penderita filariasis mengalami tekanan psikososial dan merasa tidak berharga bagi lingkungan dan keluarga karena adanya perubahan citra tubuh dan keterbatasan fisik. Faktor psikososial berperan dalam pembentukan stigma terhadap penderita oleh lingkungan dan keluarga. Ketika mengetahui bahwa dirinya menderita filariasis, sebagian besar penderita akan terkejut, sedih, malu, bahkan ada 
yang putus asa dan kehilangan makna hidup (Nihayati, 2012). Persepsi terhadap penyakit yang diderita ditunjukkan dengan adanya perubahan perilaku, seperti: lebih banyak di rumah, menghindari dan membatasi diri, serta menarik diri karena merasa malu dengan perubahan citra tubuh dan takut akan perlakuan negatif dari masyarakat (Sedjati, 2015). Hal ini dapat berdampak pada respons sosial dan emosional penderita, yaitu adanya stigma sosial yang dapat menyebabkan gangguan perilaku pada orang lain, termasuk menghindari kontak fisik dan sosial (Nihayati, 2012). Hasil penelitian Hadisiwi dan Mulyani (2013) di Bandung menjelaskan bahwa terdapat beberapa karekteristik sosial pada penderita filariasis yang dapat berdampak pada dimensi psikososial, salah satunya status perkawinan. Dalam penelitian tersebut ditemukan bahwa penyakitnya merupakan salah satu alasan perempuan penderita filariasis merasa takut menikah.

Kecacatan fisik membuat penderita mudah merasa lelah secara fisik. Hal ini disebabkan karena terjadinya pembengkakan pada anggota tubuh yang membuat penderita membutuhkan banyak energi daripada orang normal untuk mobilisasi (Kusumadewi, 2012). Hambatan fisik yang dialami akan menimbulkan tekanan psikologis pada penderita filariasis, seperti: depresi, cemas, hilangnya tujuan hidup, dan melemahnya produktivitas (Ardias, Setiani, \& Darundiati, 2012). Selain itu, penderita akan mengalami keterbatasan dalam aktivitas sosial, merasa cemas, dan mudah tersinggung karena kurangnya peran dan tanggung jawab dalam kegiatan sosial (Kusumadewi, 2012).

Secara umum, perubahan situasi fisik dan sosial yang dialami penderita filariasis ditanggapi dalam bentuk respons psikososial. Respons psikososial diartikan sebagai bentuk perubahan dalam kehidupan individu, baik yang bersifat psikologis maupun sosial, yang mempunyai pengaruh akan kualitas hidup seseorang. Respons psikososial penderita cenderung berfokus pada pemikiran negatif tentang masa depannya dan lebih tertutup dengan lingkungan. Selain pemikiran negatif, ada pula penderita dengan pemikiran positif yang dimanifestasikan dalam keinginan untuk berelasi dekat dengan orang lain, membangun hubungan, menunjukkan sikap kasih sayang, serta memberikan perhatian terhadap kebahagiaan diri sendiri dan orang lain. Pemikiran positif ini mengarahkan penderita untuk mencapai kesejahteraan psikologis.

Kesejahteraan psikologis (well-being) adalah konstruk psikologis yang memiliki dua dimensi utama, yaitu psychological well-being (kesejahteraan psikologis) dan subjective well-being (kesejahteraan subjektif) (Ryan \& Deci, 2001). Menurut Ramadhani, Djunaedi, dan Sismiati (2016), kesejahteraan psikologis bukan hanya merupakan ketiadaan penderitaan, tetapi juga meliputi keterkaitan aktif dalam dunia, memahami arti dan tujuan hidup, serta hubungan seseorang dengan 
objek ataupun orang lain. Dengan kata lain, psychological well-being merupakan suatu pencapaian penuh dari potensi psikologis individu dan suatu keadaan, di mana individu dapat menerima kekuatan dan kelemahan dirinya, memiliki tujuan hidup, mengembangkan relasi yang positif dengan orang lain, menjadi pribadi yang mandiri, mampu menciptakan lingkungan yang nyaman, dan terus bertumbuh secara personal (Ryan \& Deci, 2001). Penelitian Hadisiwi dan Mulyani (2013) membuktikan bahwa penderita yang memiliki psychological well-being adalah penderita yang menerima kelemahan dirinya, meskipun dirinya mengalami kecacatan yang diakibatkan oleh filariasis. Namun, banyak penderita filariasis yang memiliki pandangan negatif terhadap dirinya sendiri. Hal ini membuat penderita sulit untuk memahami dirinya sendiri (Sofiana, Elita, \& Utomo, 2012). Konsep diri yang negatif berpengaruh terhadap ketidakmampuan penderita filariasis untuk menerima kondisi fisik apa adanya, sehingga berdampak pada aspek psychological well-being.

Perubahan yang dialami penderita filariasis dengan adanya pembengkakan sampai mengeluarkan nanah ataupun darah seringkali akan menambah tekanan berupa kecemasan, sehingga membuat penderita memiliki pandangan negatif tentang masa depannya dan merasa masa depannya akan suram (Nindyasari, 2010). Menurut Ryff (1995), pandangan negatif terhadap masa depan dapat memengaruhi psychological well-being. Hal ini juga ditekankan Nindyasari (2010) bahwa masalah yang timbul akibat filariasis berpengaruh terhadap respons psikososial seseorang yang berdampak pada kesejahteraan psikologis.

Berdasarkan pemaparan di atas, tujuan penelitian ini adalah untuk mendeskripsikan respons psikososial dan kesejahteraan psikologis pasien filariasis.

\section{METODE}

\section{Partisipan}

Partisipan direkrut melalui metode purposive sampling. Kriteria partisipan dalam penelitian ini ialah pasien yang telah didiagnosa menderita filariasis, berusia 18-70 tahun, berdomisili di Kota Ambon, dan bersedia menjadi partisipan penelitian. Berikut adalah karakteristik partisipan yang dapat dilihat pada Tabel 1 di bawah ini. 
Tabel 1.

Karakteristik Partisipan

\begin{tabular}{lcc}
\hline & Partisipan I (P1) & Partisipan II (P2) \\
\hline Usia & 51 tahun & 18 tahun \\
Jenis Kelamin & Perempuan & Perempuan \\
Pekerjaan & Ibu Rumah Tangga & Tidak bekerja \\
Lama Diderita & 28 tahun & 13 tahun \\
Pengobatan & Diethycarbamazine (DEC) & Diethycarbamazine (DEC) \\
\hline
\end{tabular}

\section{Desain}

Metode dalam penelitian ini adalah kualitatif dengan desain studi kasus. Metode ini dipilih karena peneliti ingin mengetahui lebih dalam tentang dinamika respons psikososial, baik secara internal maupun eksternal, sekaligus untuk melihat mana yang lebih memengaruhi munculnya respons psikosial. Selain itu, peneliti juga ingin melihat apakah respons psikososial yang muncul berupa respons positif atau respons negatif, serta bagaimana cara partisipan berespons untuk mencapai kesejahteraan psikologis. Tipe penelitian yang digunakan adalah deskriptif yang bertujuan untuk memperoleh informasi-informasi mengenai keadaan saat ini dan melihat kaitan antara variabel-variabel yang ada (Gulo, 2000).

\section{Prosedur}

Teknik pengumpulan data pada penelitian ini menggunakan wawancara mendalam, di mana data pasien yang telah didiagnosa filariasis akan menjadi data dasar atau utama dalam memilih informan. Selain itu, teknik observasi juga digunakan sebagai data pendukung (Pawito, 2007).

\section{Teknik Analisis}

Data yang dikumpulkan akan dianalisa dengan teknik analisis interaktif yang mengacu pada teori Miles dan Huberman (1984), yang mengemukakan bahwa data akan dianalisis secara terusmenerus sampai tuntas, sehingga memperoleh data yang jenuh. Artinya, data akan diproses sampai tidak memperoleh lagi informasi baru. Teknik analisa ini pada dasarnya terdiri dari tiga komponen, yaitu redukasi data (data reducation), penyajian data (data display), penarikan data, serta pengujian kesimpulan (drawing and verifying concuclusions) (Rahardjo, 2010). 


\section{ANALISIS DAN HASIL}

Hasil analisa konten memunculkan empat tema utama, yaitu: tidak dikucilkan, optimis, dampak negatif, dan hubungan sosial.

\section{Tidak Dikucilkan}

Dalam penelitian ini, partisipan tidak dikucilkan oleh masyarakat dan masyarakat menerima kondisi yang dialami partisipan. Partisipan beruntung dan senang mendapatkan lingkungan yang baik.

"Malahan mereka terima saya apa adanya. Untung dan senangnya saya mendapatkan lingkungan yang baik. Tapi kalau di lingkungan yang lain? Belum tentu mereka mau terima." (P1)

"Banyak yang bilang kalau dekat-dekat nanti akan menular tapi walaupun banyak yang mengatakan seperti begitu tapi tidak membuat mereka takut, malahan temanteman sering datang bermain ke rumah." (P2)

\section{Optimis}

Penyakit yang diderita tidak pernah membuat partisipan merasa putus asa atau menjadikan diri mereka lemah. Justru, hal tersebut membuat mereka memiliki keinginan yang kuat untuk sembuh. Keinginan tersebut dilakukan dengan cara mengomsumsi obat Diethycarbamazine (DEC) secara rutin. Obat ini merupakan obat bagi penderita filariasis untuk mematikan cacing filaria dewasa yang biasanya diberikan oleh perawat. Pengobatan tersebut memberikan dampak positif, yaitu dapat berjalan, bekerja, dan melayani keluarga walaupun dengan keterbatasan yang dimiliki. Kondisi tersebut menimbulkan rasa optimis dan membuat mereka tidak memikirkan perkataan orang lain tentang dirinya dan penyakit yang dialaminya.

"Mengobati dan terpenting kita percaya. Kalau ada perawat yang datang melayani untuk memberikan obat untuk minum, saya minum karena ada keinginan untuk sembuh." (P1)

"Kalau mereka perhatikan saya tidak terlalu ambil pusing... Dan yang menjadi prinsip saya itu selalu rasa senang, suka cita, dan damai sejahtera." (P1) 
"Untuk positifnya bisa berjalan seperti biasa, bekerja seperi biasa, bisa melayani anak dan cucu, kalau ada rapat di sekolah saya pergi, ambil rapot saya pergi baik itu anak-anak masih SD, SMP, dan SMA saya tetap pergi." (P1)

"Saya pasti sembuh, jadi obat yang saya dapat saya minum karena saya tahu pasti akan sembuh. Untuk mewujudkannya dengan saya rutin minum obat dan sholat."(P2)

"Biasa-biasa saja, tidak terlalu ambil pusing, mau mereka bilang apa saya cuek saja.” (P2)

\section{Dampak Negatif}

Dampak negatif yang sering dirasakan partisipan adalah tidak merasa bebas karena sulit berjalan, tidak dapat beraktivitas seperti biasa, dan sulit dalam berpakaian. Untuk itu, partisipan lebih sering bergantung pada keluarga atau orang lain. Hal yang sering diminta bantuan dari partisipan, yaitu: mandi, berpakaian, dan mengangkat barang berat. Di samping itu, partisipan juga sering mendapatkan perlakuan negatif, seperti selalu diejek oleh teman-teman, bahkan ada beberapa orang yang tidak mau bermain dengan mereka. Namun, hal tersebut membuat partisipan tidak merasa rendah diri atau menutup diri.

"Tidak bisa berjalan seperti orang yang sempurna kalau orang yang sempurna kan bisa berpakaian apa saja dengan kondisi apapun bisa, tapi kalau saya begini rasanya, seperti mau ke mana-mana begitu, berpakaian seperti nona [peneliti] begitu, bebas-bebas saja. “(P1)

"Sering meminta tolong kepada tetangga, kalau misalnya tidak ada anak-anak ya berarti tetangga. Biasanya kalau saya lagi menampung air di tetangga sebelah situ, saya minta tolong angkatin airnya saya dulu. ”(P1)

"Harus memakai kursi roda karena sulit bergerak. Untuk aktivitas yang lain tidak bisa dilakukan, harus ada bantuan dari mama atau nenek.” (P2)

"Ya, palingan angkat barang-barang berat atau ambil sesuatu yang ada di tempat tinggi begitu baru minta tolong tapi kalau untuk makan, minum tidak pernah.” (P2)

"Ya, walaupun diejekin tapi saya tidak terlalu ambil pusing tapi kadang-kadang saya juga sering marahin teman-teman kalau diejekin kayak begitu atau saya laporin mama." (P2) 


\section{Hubungan Sosial}

Hubungan sosial partisipan dengan orang lain sangat baik, walaupun partisipan memiliki keadaan fisik yang dapat membuat orang lain takut. Namun, hal tersebut tidak membuat partisipan berhenti bergaul atau menutup diri. Partisipan bergaul setiap harinya seperti tidak terjadi apa-apa pada dirinya. Partisipan tidak malu dengan keadaan yang dialaminya sekarang, bahkan partisipan selalu mengambil bagian dalam setiap kegiatan yang ada. Kegiatan-kegiatan tersebut, yaitu: berorganisasi, memimpin ibadah, menjadi penagih iuran jemaat, dan mengikuti perlombaan di sekolah atau saat hari raya. Kegiatan yang diikuti menjadi cara partisipan membina hubungan dengan orang lain.

"Oh iya, kepuasan tersendiri. Bergaul setiap hari seperti biasa terus kalau di organisasi ada perlu apa saya ambil bagian.” (P1)

"Tidak lagi, tapi ada yang datang minta kesediaan saya untuk pimpin ibadah, saya terima. Kalau untuk pengurus wadah tidak lagi soalnya mereka berpikir kondisi yang sudah kurang baik. Awalnya masih jadi pengurus tapi sudah tidak lagi. Tapi masih menjadi penangih uiran di jemaat sini, sector dan di unit." (P1)

"Selalu mengambil bagian dengan teman-teman kalau mereka lagi main, ada juga teman-teman sering datang bermain di rumah. Jadi hubungan saya dengan temanteman baik." (P2)

"Tidak ada, palingan waktu SD atau waktu lebaran-lebaran begitu kalau misalnya ada lomba-lomba begitu saya ikuti." (P2)

\section{DISKUSI}

Penelitian ini menunjukkan bahwa perubahan fisik yang dialami partisipan memberi dampak negatif berupa terganggunya aktivitas sehari-hari. Dampak ini menjadikannya tidak dapat beraktivitas secara bebas layaknya orang lain yang tidak sakit. Kondisi ini didukung oleh penelitian yang dilakukan oleh Wijesinghe, Wickremasinghe, Ekanayake, dan Perera (2007) bahwa pasien filariasis mengalami kesulitan untuk berjalan, sehingga memengaruhi kinerja. Keterbatasan fisik inilah yang mengakibatkan adanya ketergantungan partisipan terhadap keluarga maupun orang lain dalam aktivitas sehari-hari. Semenjak mengalami filariasis, partisipan lebih sering meminta bantuan kepada orang lain. Hasil penelitian ini pun pernah dinyatakan oleh Kumari, Harichandrakumar, 
Das, dan Krishanmoorthy (2005) bahwa penurunan kemampuan mobilisasi merupakan hal terbesar dari kecacatan filariasis. Artinya, kemampuan pasien filariasis terbatas di tempat tidur. Oleh karena itu, aktivitas sehari-hari pasien tergantung pada keluarga.

Di samping itu, partisipan juga mengalami perlakuan negatif. Perlakuan negatif yang didapat berupa ejekan yang menyebutnya dengan istilah 'kaki gajah'. Kondisi itu membuat dirinya terisolasi secara sosial karena tidak ada yang mau berinteraksi dengannya. Walaupun demikian, hal tersebut tidak membuat dirinya menjadi minder atau membuat partisipan menutup diri.

Hasil penelitian ini sangat bertolak belakang dengan hasil penelitian Sulianti (2014) yang menyatakan bahwa pasien filariasis malu menderita penyakit yang dialaminya, sehingga pasien filariasis menyembunyikan diri di dalam rumah dan tidak memberi tahu tetangga atau kerabatnya, kecuali kerabat yang tinggal di rumah. Meskipun respons yang diterima partisipan dari lingkungan cenderung negatif, tetapi hal tersebut justru membuat partisipan lebih mengarah pada pemikiran positif. Pemikiran postif yang muncul didapat dari adanya penerimaan dan dukungan keluarga terhadap partisipan, sehingga membuat partisipan merasa senang dan bersemangat dalam menjalani hidup. Ryff dan Keyes (1995) menyatakan bahwa perhatian, perasaan dicintai, pengakuan, dan pertolongan yang dirasakan oleh seseorang dari lingkungan sosialnya melalui orang-orang terdekat diartikan sebagai dukungan sosial. Partisipan tidak dikucilkan oleh lingkungan dan lingkungan juga menerima kondisi yang dialami partisipan. Hal ini yang akan mengarahkan penderita untuk mencapai kesejahteraan psikologis.

Dalam penelitian ini, partisipan memiliki kesejahteraan psikologis yang ditunjukkan dengan mengucap syukur karena masih dapat berjalan walaupun dengan keterbatasan fisik. Inilah yang membuat partisipan berkeinginan untuk sembuh. Cara yang dilakukan adalah dengan rutin mengonsumsi obat program Diethycarbamazine (DEC) yang diberikan, memiliki prinsip untuk tetap melanjutkan hidup, dan tidak terlalu memikirkan perkataan orang lain. Partisipan tetap menjalin hubungan sosial dengan lingkungan dengan cara terlibat dalam kegiatan organisasi, mengikuti perlombaan, atau beribadah. Hal inilah yang membuat hubungan sosial partisipan dengan lingkungannya sangat baik. Kondisi di atas sejalan dengan penelitian Hadisiwi dan Mulyani (2013) yang membuktikan bahwa kesejahteraan psikologis dimiliki ketika penderita mampu menerima kelemahan dirinya, meskipun mengalami kecacatan yang diakibatkan penyakit filariasis. Menurut Ryff (1989), psychological well-being dapat tercapai bila seseorang dapat memahami dan menerima dirinya dengan memiliki pandangan positif terhadap diri sendiri dan orang lain, percaya diri dalam membuat keputusan dan bersikap, mampu mengatur dan beradaptasi dengan lingkungan sesuai 
kebutuhan hidupnya, memaknai hidup sebagai proses yang berarti, serta berusaha mengembangkan potensi diri.

\section{SIMPULAN DAN SARAN}

\section{Simpulan}

Penelitian ini mendeskripsikan respons psikososial penderita filariasis dalam kaitannya untuk mencapai kesejahteraan psikologis. Kategori yang muncul, yaitu: tidak dikucilkan, optimis, dampak negatif, dan hubungan sosial. Kecacatan yang dialami partisipan akibat filariasis mengakibatkan dirinya harus hidup dengan ketergantungan terhadap orang lain dan mendapat perlakuan negatif dari lingkungannya. Walaupun dampak tersebut harus dialami setiap harinya, partisipan tetap dapat mencapai kesejahteraan psikologis, terutama ketika mereka menyadari bahwa ia tidak dikucilkan oleh lingkungan keluarganya, sehingga memunculkan adanya rasa optimis. Hal itulah yang menjadikan partisipan tetap mampu dan terus berupaya untuk menjalin relasi sosial dengan lingkungannya yang lebih luas.

\section{Saran Teoretis}

Penelitian selanjutnya dapat menambahkan strategi untuk mengatasi respons psikososial yang muncul demi tercapainya kesejahteraan psikologis pada pasien filariasis. Hal ini dikarenakan pada penelitian ini belum dapat membahas respons psikososial secara luas dan lengkap karena di luar lingkup penelitian ini.

\section{Saran Praktis}

Hasil penelitian ini merekomendasikan kunci utama untuk mencapai kesejahteraan psikologis pada penderita filariasis, yaitu dukungan keluarga dan kepercayaan diri. Dukungan keluarga menjadi dasar seseorang dapat melewati masalah yang dialaminya, meskipun sulit. Kepercayaan diri membuat seseorang mempunyai keyakinan atau merasa mampu untuk mencapai berbagai tujuan di dalam hidupnya dengan adanya motivasi dalam diri sendiri untuk lebih mau menghargai dirinya. 


\section{REFERENSI}

Aprilliani, P. F., \& Mustafidah, H. (2017). Implementasi certainty factor pada diagnosa penyakit infeksi tropis. Jurnal Riset Sains dan Teknologi, 1(1), 22-36.

Ardias, A., Setiani, O., \& Darundiati, Y. H. (2012). Environmental and community behavior factor associated with the incidence of filariasis in Sambas District. Jurnal Kesehatan Lingkungan Indonesia, 11(2), 199-207. doi: 10.14710/jkli.11.2.199-207

Dinas Kesehatan Indonesia (2015). Profil Kesehatan Indonesia 2014. Ditemu kembali dari http://www.depkes.go.id/resources/download/pusdatin/profil-kesehatan-indonesia/profilkesehatan-indonesia-2014.pdf

Dinas Kesehatan Maluku. (2015). Profil kesehatan Provinsi Maluku 2014. Ditemu kembali dari http://www.depkes.go.id/resources/download/profil/PROFIL_KES_PROVINSI_2014/31_ Maluku_2014.pdf

Gulo, W. (2000). Metode penelitian. Jakarta: Grasindo.

Hadisiwi, P., \& Mulyani, H. S. (2013). Profil penyandang filariasis di Kabupaten Bandung. Jurnal Kajian Komunikasi, 1(2), 125-132.

Infodatin. (2016). Situasi filariasis di Indonesia tahun 2015. Ditemu kembali dari http://www.depkes.go.id/download.php?file=download/pusdatin/infodatin/InfodatinFilariasis-2016.pdf

Kementerian Kesehatan RI. (2010). Profil kesehatan Indonesia 2009. Ditemu kembali dari http://www.depkes.go.id/resources/download/pusdatin/profil-kesehatan-indonesia/profilkesehatan-indonesia-2009.pdf?opwvc=1

Kementerian Kesehatan RI. (2019). Profil kesehatan Indonesia 2018. Ditemu kembali dari http://www.depkes.go.id/resources/download/pusdatin/profil-kesehatan-indonesia/profilkesehatan-indonesia-2018.pdf

Kumari, A. K., Harichandrakumar, K. T., Das, L. K., \& Krishanmoorthy, K. (2005). Physical and psychosocial burden due to lymphatic filariasis as perceived by patients and medical experts. Tropical Medicine and International Health, 10(6), 567-573.

Kusumadewi, M. D. (2012). Peran stresor harian, optimisme dan regulasi diri terhadap kualitas hidup individu dengan diabetes melitus tipe 2. Psikoislamika, 8(1), 43-61.

Masrizal. (2013). Penyakit filariasis. Jurnal Kesehatan Masyarakat, 7(1), 43-44.

Milles, M. B., \& Huberman, M. A. (1984). Qualitative data analysis. London, UK: Sage 
Publication.

Nihayati, A. (2012). Dukungan sosial pada penyandang HIV/AIDS dewasa (Skripsi tidak dipublikasikan). Universitas Muhammadiyah Surakarta, Indonesia.

Nindyasari, N. D. (2010). Perbedaan tingkat kecemasan pada penderita diabetes mellitus (DM) tipe I dengan diabetes mellitus (DM) tipe II (Skripsi tidak dipublikasikan). Universitas Sebelas Maret Surakarta, Indonesia.

Noerjoedianto, D., Ekawaty, F., \& Herwansyah. (2013). Pengaruh karakteristik kepala keluarga terhadap tindakan pencegahan penyakit filariasis di Desa Kemingking dalam Kabupaten Muaro Jambi Propinsi Jambi tahun 2012. Jurnal Penelitian Universitas Jambi Seri Sains, 15(2), 55-60.

Pawito. (2007). Penelitian komunikasi kualitatif. Yogyakarta: LKis Pelangi Aksara.

Rahardjo, M. (2010). Triangulasi dalam penelitian kualitatif (Skripsi tidak dipublikasikan). Universitas Islam Negeri Maulana Malik Ibrahim, Malang, Indonesia.

Ramadhani, T., Djunaedi, \& Sismiati, A. S. (2016). Kesejahteraan psikologis (psychological wellbeing) siswa yang orangtuanya bercerai (studi deskriptif yang dilakukan pada siswa di SMK Negeri 26 Pembangunan Jakarta). Jurnal Bimbingan Konseling, 5(1), 108-115.

Ryan, R. M., \& Deci, E. L. (2001). On happiness and human potentials: A review of research on hedonic and eudaimonic well-being. Annual Review of Psychology, 52, 141-166. doi: 10.1146/annurev.psych.52.1.141

Ryff, C. D. (1989). Happiness is everything, or is it? Exploration on the meaning of psychological well-being. Journal of Personality and Social Psychological, 57(6), 1060-1081.

Ryff, C. D. (1995). Psychological well-being in adulthood. Current Directions in Psychological Science, 4(4), 99-104.

Ryff, C. D., \& Keyes, C. (1995). The structure of well-being. Journal of Personality and Social Psychology, 69(4), 719-727.

Sedjati, F. (2015). Hubungan antara efikasi diri dan dukungan sosial dengan kebermaknaan hidup pada penderita tuberkulosis paru di Balai Pengobatan Penyakit Paru-Paru (BP4) Yogyakarta (Skripsi tidak dipublikasikan). Universitas Ahmad Dahlan Yogyakarta, Indonesia.

Sofiana, L. I., Elita, V., \& Utomo, W. (2012). Hubungan antara stress dengan konsep diabetes mellitus tipe 2. Jurnal Ners Indonesia, 2, 167-176.

Sulianti, A. (2014). Tinjauan psikologi kesehatan pada penderita penyakit kaki gajah kronis di 
Kabupaten Bandung. Psympathic, 1(2), 186-203. doi: 10.15575/psy.v1i2.477

Wijesinghe, R. S., Wickremasinghe, A. R., Ekanayake, S., \& Perera, M. S. (2007). Physical disability and psychosocial impact due to chronic filarial lymphoedema in Sri Lanka. Filaria Journal, 6(1), 1-8. doi: 10.1186/1475-2883-6-4

World Health Organization. (2016). Neglected diseases: Lymphatic filariasis. Ditemu kembali dari http://www.who.int/gho/neglected_diseases/lymphatic_filariasis/en/ 